\title{
Role of ficus carica Leaves Extract in Treatment of Hypothyroidism
}

\author{
Abbas Abed Sharhan ${ }^{\text {a }}$ \\ Kareem H. Rasheed ${ }^{b}$ \\ Alaa J.Hassan ${ }^{c}$ \\ ${ }^{a}$ College of biotechnology, Al-Qassim green university \\ ${ }^{b, c}$ College of science, Biology department, University of Babylon \\ abbas07810068843@gmail.com
}

Submission date:- 22/5/2018 Acceptance date:- 11/7/2018 Publication date:- 12/12/2018

Keywords: Hypothyroidism, thyroid gland, carbimazole , Ficus carica , phytochemicle component.

\begin{abstract}
This study was conducted to demonstrate the role of alcoholic extract from ficus carica leaves in the treatment of hypothyroidism disease which induced by carbimazole drug. Forty male rats were divided into five groups, eight for each . group I selected as negative control and administered orally with normal saline alone, group II served as positive control and treated by carbimazole anti-thyroid drug for six weeks, group III was treated by plant extract $(500 \mathrm{mg}$ $/ \mathrm{kg}$, bw) for six weeks, the fourth group IV was treated by carbimazole drug $(5 \mathrm{mg})$ for six week to induce hypothyroidism and then treated by plant extract $(500 \mathrm{mg} / \mathrm{kg}$, bw), and the fifth $\mathrm{V}$ group was treated by thyroxin drug $(100 \mathrm{mg})$ for six week instead of plant extract.

The results showed insignificant differences $(\mathrm{P}<0.05)$ in body weight gain in the fourth group ( carbimazole and plant extract) when compared with the first group (normal saline alone), second group (carbimazole alone), third group (plant extract alone, while the results demonstrated that a significant increase $(\mathrm{P}<0.05)$ in body weight gain when compared with fifth groups (carbimazole and thyroxine). While the results revealed insignificant differences $(\mathrm{P}<0.05)$ in the concentrations of T3 and T4 in the fourth (carbimazole \& plant extract), fifth groups (carbimazole \& thyroxin drug ) and the third group (plant extract alone) when compared with the first group ( normal saline alone), but there was a significant increase $(\mathrm{P}<0.05)$ when compared with the second group (carbimazole alone), in addition the results indicated a significant decrease $(\mathrm{P}<0.05)$ when compared with the third group, Furthermore, the results revealed insignificant difference $(\mathrm{P}<0.05)$ in TSH concentration in the fourth (carbimazole \& plant extract), fifth groups (carbimazole \& thyroxin drug) and the third group (plant extract alone) when compared with the first group (normal saline alone), also the data showed a significant decrease $(\mathrm{P}<0.05)$ when compared with the second group (carbimazole alone). In conclusion, it is possible to use methanolic plant extract from ficus carica leaves in the regulation of hypothyroidism due to the presence of phytochemical components that can be affect the mechanism of T3 and T4 production by the thyroid gland.
\end{abstract}

\section{1- Introduction:}

Thyroid gland is one of the most important endocrine glands in animal and human body. It has an important role in regulating body metabolism, central nervous system activity, and the regulation of all the physiological activities of different organs and tissues such as the liver and the heart [1]. The thyroid gland secretes two important hormones: triiodothyronine (T3) and tetraiodothyronine called (T4) which have essential role in regulating the metabolism process in every cell inside the body. They can promote growth process, development, function and maintenance of all body tissues. They act as regulator of heart rate, body temperature, cholesterol and body weight [2].

Hypothyroidism means suppression of thyroid function [3] and can be divided into :firstly Primary hypothyroidism which is due to thyroid gland disorder leading to decreased circulation of thyroid hormones or failure to produce enough thyroid hormone and the second type is called secondary hypothyroidism that caused by a disorder of the pituitary gland or the hypothalamus axis which lead to decreased TSH synthesis and then to decreased synthesisand secretion of thyroid hormones. [4]. Hypothyroidism disease are diagnosed by low level of (T4) and (T3) and high level of thyroid-stimulating hormone (TSH)[5]. Ficus carica Linn. (Moraceae) known as the fig plant, is grown and 
agriculture in tropical and sub-tropical regions. [6] analyses by using HPTLC to identify Phytochemical components revealed to presence of amino acid tyrosine in the extract from leaf which may be helping or responsible from thyroidal activity when using Ficus carica leaf extract as treatmen. The aim of this study was to determine how leaves of ficus carica regulate the thyroid hormones levels and how it can plays ameliorative role when used for pharmaceutical purposes to treat hypothyroidism .

\section{2- Materials and Methods}

\subsection{Preparation of extract}

Fresh leaves of ficus carica were collected from local farms during July 2017 . For the preparation of the methanolic leaves extract, leaves washed up in a tap water and distilled water, and then dried for about 2 weeks in shadow and then crushed into a coarse powder by using a blender, amount of 200 gm of the coarse powder was kept soaked in methanol $(1 \mathrm{~L}, 99 \%)$ and then soxhulat apparatus and rotary evaporator were used in order to get the extract which was stored in refrigerator $4 \mathrm{c}$ until a suspension of this extract was used to treat the animal .

Forty (40) male rats were divided into five groups, eight animals for each. First group served as a negative control and administered orally with normal saline alone for six weeks. The second group used as positive control was treated with anti-thyroid carbimazole drug $(5 \mathrm{mg} / \mathrm{kg}$, bw) for six weeks, the third group was treated with plant extract ( 500 $\mathrm{mg} / \mathrm{kg}$, bw) for six weeks, the fourth group was administrated by carbimazole drug $(5 \mathrm{mg} / \mathrm{kg}$, bw) for six week to induce hypothyroidism and then treated by plant extract $(500 \mathrm{mg} / \mathrm{kg}$, bw) for six weeks too, while the fifth group was treated by carbimazole drug $(5 \mathrm{mg} / \mathrm{kg}$, bw) for six week to induce hypothyroidism and then treated by thyroxin drug $(100 \mathrm{mg} / \mathrm{kg}$, bw) for six week too instead of plant extract.

Hypothyroidism was stimulated by antithyroid drug called carbimazole which is using in the treatment of human hyperthyroidism disease [7]. Change in the thyroid gland functions may related to disorder in hormones synthesis was recorded. Rats body weight were measured before and after treatment, and animals were sacrificed after 48 hours of last administration of the drugs and plant extract. The blood was collected from the left ventricle of the heart through heart puncture, and the blood samples allowed to stand for 1 hour at a room temperature and later centrifuged at 3000 $\mathrm{rpm}$ for $15 \mathrm{~min}$ to obtain serum which served in deep freez. Thyroid hormones T3, T4 and TSH were measured by using Elisa Colbiotech kits (U.S.A).

\subsection{Statistical analysis}

The data were analyzed as mean \pm S.E (standard error mean) for eight rats. Statistical analysis were carried out by using SPSS software [version 17]. Differences among control and experimental groups were assessed using one- way anova and Duncan, least significant differences (L.S.D) . probability less than $\mathrm{P}<0.05$ [8].

\section{3- Results}

\subsection{Animals body weight gain}

At the beginning of the experiment the mean weight values in all groups were semi convergent but the differences started as time passed. The results showed (table-1) insignificant differences $(\mathrm{P}<0.05)$ in body weight gain in the fourth group ( carbimazole and plant extract ) when compared with the first group (normal saline alone), second group (carbimazole alone), third group (plant extract alone, while the results demonstrated that a significant increase $(\mathrm{P}<0.05)$ in body weight gain when compared with fifth groups (carbimazole and thyroxine).

Table -1: Effects of alcoholic extract of Ficus carcia leaves on the body weight gain (Mean \pm S.E)

\begin{tabular}{|c|c|}
\hline Group names & Body Weight gain (gm) \\
\hline Group I (normal saline) & $85.5 \pm 6.7 \mathrm{a}$ \\
\hline Group II (carbimazole) & $\mathbf{8 9} \pm 5.6 \mathrm{a}$ \\
\hline Group III (plant extract) & $79 \pm 4.4 \mathrm{a}$ \\
\hline Group V(carbimazole \& plant extract) & $\mathbf{7 8} \pm 5.8 \mathrm{a}$ \\
\hline Group VI (carbimazole \& thyroxin) & $25 \pm 2.8 \mathrm{c}$ \\
\hline
\end{tabular}

Note : Different letters indicate the presence of a significantly differences $(P \leq 0.05)$. 
The results revealed insignificant differences $(\mathrm{P}<0.05)$ in the concentrations of $\mathrm{T} 3$ and $\mathrm{T} 4$ in the fourth group (carbimazole \& plant extract), fifth groups (carbimazole \& thyroxin drug ) and the third group (plant extract alone) when compared with the first group ( normal saline alone), but there was a significant increase $(\mathrm{P}<0.05)$ when compared with the second group (carbimazole alone).

Table 2 : The effect of methanolic extract of Ficus carcia leaves on the sera levels of T3 and T4 hormones.

\begin{tabular}{|c|c|c|}
\hline Parameters & $\begin{array}{c}\text { T3 ng/ml } \\
\text { Mean } \pm \text { S.E }\end{array}$ & $\begin{array}{c}\text { T4 ug/dl } \\
\text { Mean } \pm \text { S.E }\end{array}$ \\
\hline Group I (normal saline) & $0.69 \pm 0.203 \mathrm{a}$ & $1.50 \pm 0.115 \mathrm{a}$ \\
\hline Group II (carbimazole alone) & $0.40 \pm 0.050 \mathrm{~b}$ & $\mathbf{0 . 9 7 \pm 0 . 1 8 6 ~ b}$ \\
\hline Group III (plant extract alone) & $1.09 \pm 0.141 \mathrm{c}$ & $\mathbf{2 . 1 5 \pm 0 . 0 9 6 \mathrm { c }}$ \\
\hline Group VI (carbimazole \& plant extract & $0.71 \pm 0.430 \mathrm{a}$ & $1.68 \pm 0.095 \mathrm{a}$ \\
\hline Group V (carbimazole \& & & $1.75 \pm 0.050 \mathrm{a}$ \\
\hline thyroxin) & $0.83 \pm 0.012 \mathrm{a}$ & \\
\hline
\end{tabular}

Note : Different letters indicated a significant differences at $\mathbf{P} \leq \mathbf{0 . 0 5}$.

Furthermore, the results revealed a significant difference $(\mathrm{P}<0.05)$ in TSH concentration in the fourth (carbimazole \& plant extract) , fifth groups (carbimazole \& thyroxin drug) and the third group (plant extract alone) when compared with the first group ( normal saline alone ), also the data showed a significant decrease $(\mathrm{P}<0.05)$ in matching with the second group (carbimazole alone) (figure -1) .

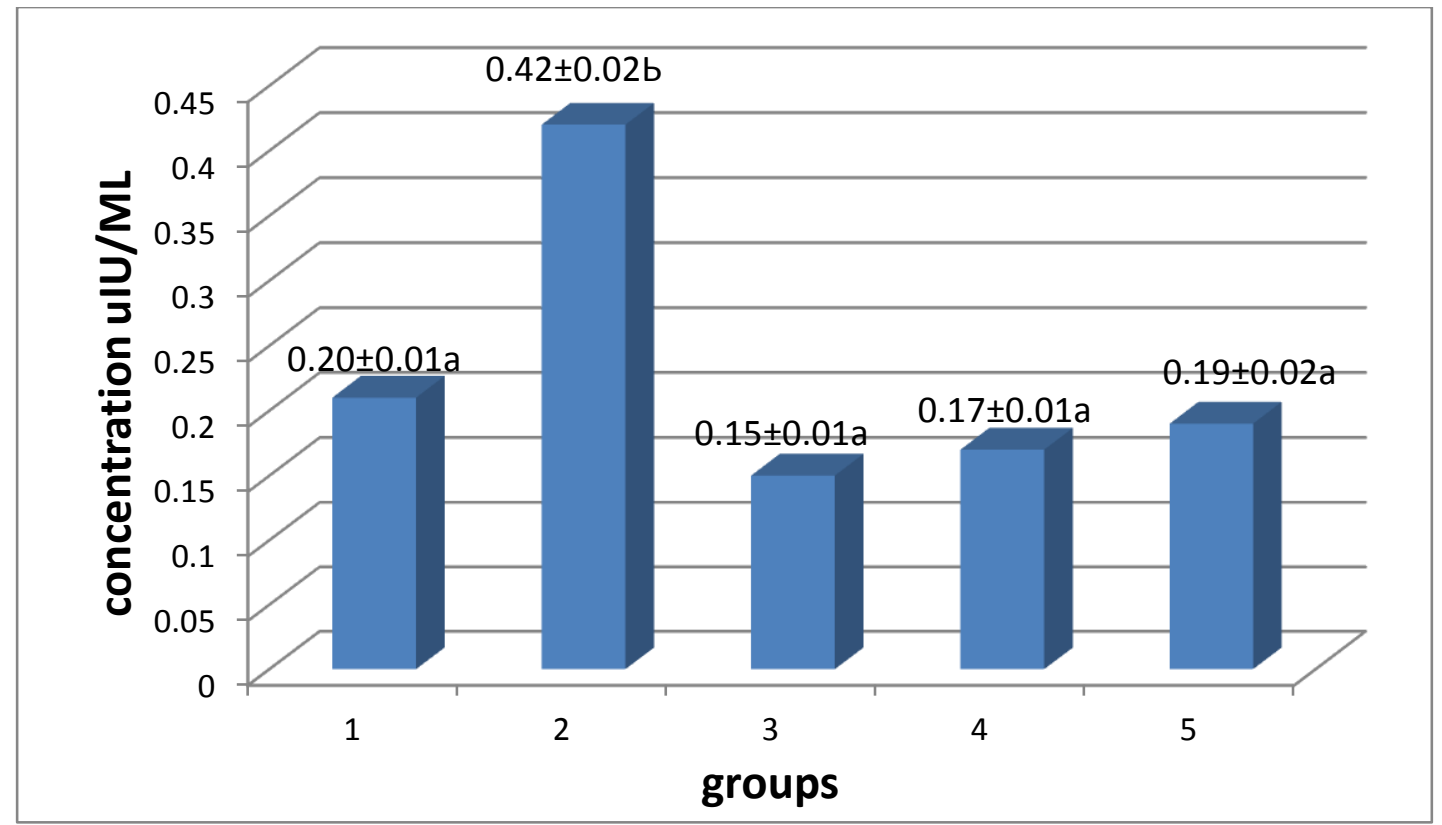

Figusre-1: Effects of alcoholic extract of Ficus carcia leaves on the serum TSH level (Mean \pm S.E), the different letters are a significant differences at $\mathbf{p} \leq \mathbf{0 . 0 5}$. 


\section{4- Discussion}

Hypothyroidism is a disorder in a general metabolism which is manifested biochemically by the decrease of the triiodothyronine and tetraiodothyronine concentration in the stream [9].

Methimazole drug may work as competitive inhibitor effects on thyroid peroxidase, thus preventing the iodination of thyrosine residues in the thyroglobulin and blocking the conversion of iodothyrosin into iodothyronine. Since the synthesis of hormones is un affected, and the effects is delayed, finally lead to decrease in the amount of the thyroid hormone [18].

However, the decline in the T4 and T3 serum concentration may related with using of dose and duration of the treatment that lead to stimulate hypothyroidism disease in the experimental animals .

The thyroid hormone imbalance and the reduction in serum T4 and T3 levels suggest the occurrence increase thyroid weights in our study (Table -2) were similar with result that are described by $[9,10]$. The theory that humans may similar with rodents animal is unfact and there may be changes in response methods and anatomical variations between different organs and functions[11]. In other studies, it was found that there was weight gain in animals with hypothyroidism, whereas this experiment showed a moderate increase in the weight of hypothyroid rats[10] .

Many plants were investigated for their ability to have hypolipaemic, antidiabetic activity and thyroid hormones regulatory roles in humans and used in experimental animals [8],[19], [12], [13] , [14], [15]. The Carbimazol treated group showed a significant increase in body weight due to increased lipolytic response and sensitivity to catecholamines in adipocytes [9].

The ability of plant extract to elevate the concentrations of thyroid hormone, may be due to increase of T4 concentration in the blood as a result of direct stimulation of $\mathrm{T} 4$ production and/or its release .

However, increase in serum T3 concentration in the third, fourth and fifth groups may occured by induce in monodeiodination of T4 in peripheral cells, which is regarded to be the major process of its synthesis. However ficus carica leaves extract can induce an increase in thyroid hormone synthesis by supression their utilization of thyroid hormones in the body.

Further experiments are essential to emphasize the mechanism of actions in thyroid hormones regulatory of Ficus carica leaf extract, the results and the present finding indicate that extract obtained from ficus carica has the ability on stimulate the thyroid gland functions [17].

\section{5- Conclusion}

From the present data can be concluded that alcoholic extract of ficus carcia leaves has a biochemical role in the regulation and controlling of the metabolic activiteis through increasing the thyroid hormones levels in the body. Moreover the results obtained from the present study showed that Ficus carica leaves methanolic extract produces stimulatory effect on thyroid follicles to elevate synthesis high amount of T3 \& T4 when used to treat hypothyroid animals .

More investigations are required to detect the effects of different doses from ficus carica leaf extract may be ameliorating in regulation hypothyroidism disease and thyroid hormone synthesis.

\section{CONFLICT OF INTERESTS}

There are no conflicts of interest.

\section{References}

[1]Ganong, $\quad$ W.F. Review $\quad$ of $\quad$ Medical Mysiology. $\quad$ McGrawHill Companies; Inc. 21th ed. pp 296-311. 2003.

[2] Duntas , L , H."Selenium and the thyroid: a close-knit connection". The Journal of Clinical Endocrinology and Metabolism. 95(12):5180-5188. 2010

[3]. Eric, Y and Kathy A. "Botnical medicine for thyroid regulation ; Alternative and Complementary";Copyright from US Library ; page no-107- 112. 2006.

[4] Michaël Friedman . "Thyroid Autoimmune Disease “. Journal of Restorative Medicine 2: 70-81. 2013.

[5]Dons, Robert, F.; Frank, J. and Wians, H. "Endocrine and Metabolic Disorders Clinical Lab Testing Manual (4th ed.)", Boca Raton: CRC Press. P: 10. 2009. 
[6] Anonymous. The Wealth of India: A Dictionary of Indian Raw Materials and Industrial Products. Vol. 4, Council of Scientific and Industrial Research, New Delhi, 25-32. 1999.

[7] Homsanit M, Sriussadaporn S, Vannasaeng S, Peerapatdit T, Nitiyanant W, Vichayanrat A. Efficacy of single daily dosage of methimazole vs. propylthiouracil in the induction of euthyroidism. Clin Endocrinol 54: 385 '90. 2001.

[8]Jawda, M. Statistical analysis by using SPSS .Dar Al-awael, Amman ,Jordan. 2008.

[9] Amara, I.B.; Bouaziz, H.; Guermazi, F. and Zeghal, N.: "Effect of selenium on hypothyroidism induced by methimazole (MMI) in lactating rats and their pups", Acta Biologica Hungarica., 61(2), 145-157. 2010.

[10] Ampong, B.;Honda, H. and Kogo, H."Effect of hypothyroidism on $\beta$-adrenoreceptormediated relaxation in the rat thoracic aortae: A time-dependent study".Vascul Pharmacol., 38: 149-155. 2002.

[11] Nida ,Q. H.; Shahnila . N.; Mah, Muneera. The Effect of Hypothyroidism on the Body Weight of Adult Albino Wistar Rats Journal of Rawalpindi Medical College (JRMC); 20(2):147-149. 2016.

[12]Viana, M., Barbas, $\mathrm{C}$ and Bonet, B. In vitro effects of a flavonoid-rich extract on LDL oxidation. Atherosclerosis123, 83-91. 1996.

[13]Laplaud, P. M., Lelubre, A., and Chapman, $\quad$ M. J. Antioxidant action of Vaccinium myrtillus extract on human low density lipoproteins in vitro: initial observations. Fundam. Clin. Pharm. ,(11), suppl. 1, 35-40. 1997.

[14]Bhardwaj, P. K., Dasgupta, D. J., Prashar, B. S., and Kaushal, S. S." Control of hyperglycaemia and hyperlipidaemia by plant product". J. Assoc. Phys. India 42, suppl. 1, 33-35. 1994.

[15]Mosihuzzaman, M., Nahar, N., Ali, L. et al.” Hypoglycemic effects of three plants from eastern Himalayan belt”. Diabetes Res. 26, suppl. 3, 127-138. 1994.

[16]Vasundhara ,S .; Dharma ,V .; Rajiv , G . and Shubhinia Saraf. "Ficus carica leaf extract in regulation of thyroidism using Elisa technique”. Asian J Pharm Clin Res, Vol 5, Issue 2, 44-48. 2012.

[17] Farwell, A.P. and Braverman, L.E. Thyroid and anti-thyroid Drugs. In: Hardman JG, Limbird LE, eds.” Goodman \& Gilman's The Pharmacological Basis of Therapeutics". 9th ed. McGraw-Hill, USA. 1383' 410. 1996.

[18] Cooper ,D.S., Kieffer ,J.D., Saxe, V., Move,r H., Maloof, F., and Ridgway, E.C.”Methimazole pharmacology in the rat:studies using a newly developed radioimmunoassay for methimazole”. Endocrinology . 114: 786'93. 1984.

أجريت هذه الدراسة لتوضيح دور المستخلص الكحولي لأوراق التين في علاج مرض قصور الغدة الدرقية المستحث بالكاربيمازول. اربعين من ذكور الجرذان البيض أختيرت وقسمت الى خمسة مجاميع وكل مجموعة ضمت ثمانية جرذان, المجموعة

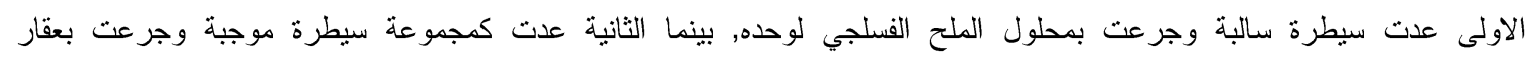

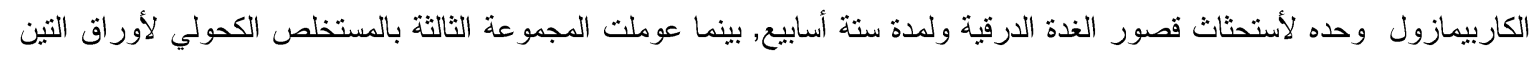

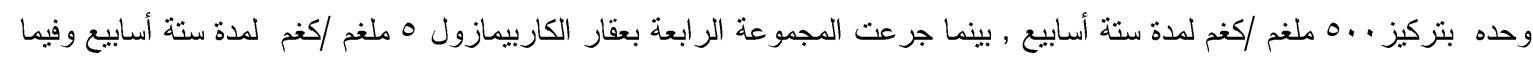

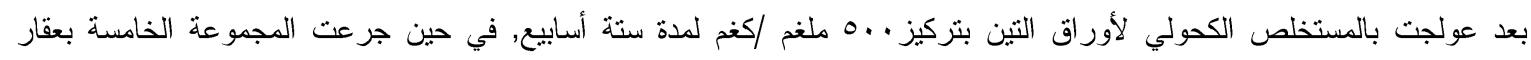
الكاربيمازول لمدة ستة أسابيع وعولجت فيما بعد بواسطة عقار الثايروكسين . ․ ملغم /كغم ولمد ستة أسابيع ايضا.

أوضحت النتائج عدم وجود فرق معنوي (P>0.05) في معدل الكسب الوزني في حيو انات المجموعة الرابعة (الكاربيمازول مع المستخلص النباتي)عند مقارنتها مع المجاميع الأولى (محلول الملح الوظيفي لوحده) و الثانية (عقار الكاربيمازول وحده) والثالثة (المستخلص النباتي لوحده) , وكذلك وجود زيادة معنوية (P<0.05) عند مقارنتها بحيو انات المجموعة الخامسة (الكاربيمازول مع عقار

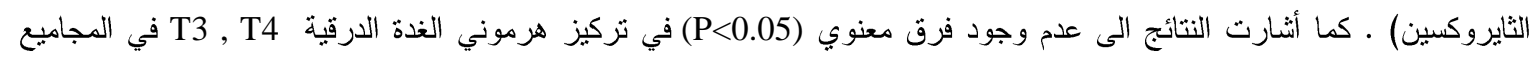

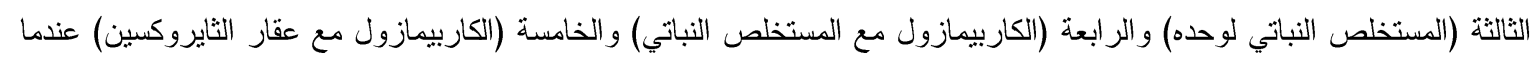

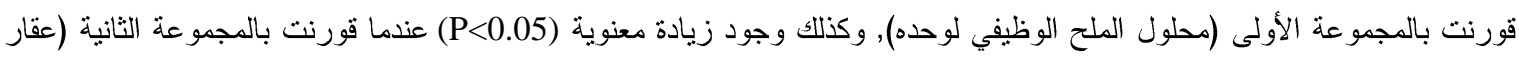

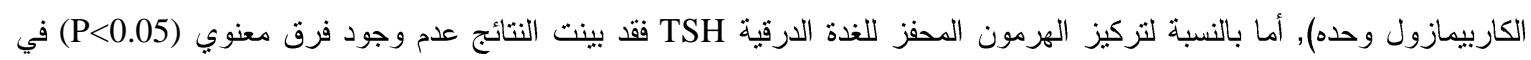
تركيز المجاميع الر ابعة (الكاربيمازول مع المستخلص النباتي) والخامسة (الكاربيمازول مع عقار الثايروكسين) و المجموعة الثالثة 
(المستخلص النباتي لوحده) عند مقارنتها بالمجموعة الأولى(محلول الملح الوظيفي لوحدة) وكذلك وجود نقص معنوي(P<0.05) عندما قورنت بالمجموعة الثانية (عقار الكاربيمازول وحده). أستتنت الدراسة الحالية أمكانية أستخدام المستخلص الميثانولي لأوراق التين في تنظيم ميكانيكية افراز هرمونات الغدة الدرقية وذلك

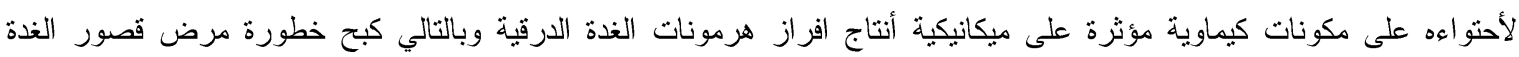
الارقية. الكلمات الدالة:قصور الغدة الدرقية, الغذة الدرقية, عقار الكاربيمازول, نبات التين, الككونات النباتية الفعالة. 